\title{
ANALISIS KUALITAS PRODUK ABON IKAN DENGAN PENDEKATAN LOGIKA FUZZY
}

\author{
A. Tutuhatunewa ${ }^{1, *}$ \\ 1Jurusan Teknik Industri Fakultas Teknik Universitas Pattimura, Ambon 97233 \\ *alfredo.tutuhatunewa@fatek.unpatti.ac.id
}

\begin{abstract}
Abstrak. Pertumbuhan industri abon ikan di kota Ambon memberikan pilihan baru cara mengkonsumsi ikan saat ini. Produk abon ikan yang diproduksi harus memenuhi kepuasan konsumen, agar konsumen tertarik untuk mengkonsumsinya. Kepuasan konsumen adalah persepsi konsumen bahwa harapannya telah terpenuhi atau terlampaui. Penelitian ini dilakukan untuk menganalisis kualitas abon ikan produksi lokal kota Ambon, berdasarkan uji organoleptik, yaitu berdasarkan penilaian warna, aroma, rasa dan tekstur abon yang paling disukai konsumen. Penilaian kualitas abon ikan yang dilakukan secara organoleptik bersifat linguistik, sehingga variabel dan penentuan parameter yang bersifat tidak pasti. Karena ketidakpastian variabel dan parameter yang digunakan, maka digunakan logika fuzzy. Hasil Penelitian menunjukkan bahwa konsumen lebih menyukai tekstur dan rasa abon ikan (nilai riil 4,1 dan 4,48). Kualitas abon ikan berada di antara domain Baik dan Sangat baik, dengan nilai riil 4,12 .
\end{abstract}

Kata kunci: Abon ikan, organoleptik, logika fuzzy.

\begin{abstract}
The growth of shredded fish industry in the city of Ambon provides a new choice how to consume fish today. Shredded fish products must meet customer satisfaction, so consumers are interested in consuming it. Customer satisfaction is the perception of customer that their expectations have been met or exceeded. This research was conducted to analyze the quality of shredded fish produced locally in Ambon city, based on organoleptic tests, which are based on the assessment of the color, aroma, taste and texture of shredded consumers most preferred. The assessment of the quality of shredded fish carried out organoleptically is linguistic, so that variables and parameter determination are uncertain. Because of the uncertainty of the variables and parameters used, fuzzy logic is used. The results showed that consumers preferred the texture and taste of shredded fish (real values 4.1 and 4.48). The quality of shredded fish is between the Good and Very Good domains, with a real value of 4.12 .
\end{abstract}

Keywords: Shredded fish, organoleptic, fuzzy logic.

\section{PENDAHULUAN}

Provinsi Maluku sebagai provinsi yang memiliki luas lautan yang begitu besar, dengan sendirinya memiliki kekayaan sumber daya laut yang beraneka ragam dan potensial untuk dikelola. Kekayaan sumber daya laut tersebut berupa sumber daya ikan maupun non ikan. Potensi ini dapat dikembangkan sebagai penghasil devisa bagi daerah maupun negara.
Dalam sistem logistik, ikan merupakan produk yang membutuhkan penanganan berbeda dibandingkan dengan komoditi lainnya [1]. Ikan adalah produk yang sangat tidak tahan lama, sehingga perlu penanganan logistik yang lebih kompleks serta biaya yang mahal, terutama untuk penyimpanannya. Ikan juga memiliki sifat umur penggunaan yang pendek serta tingkat kerentanan yang tinggi terhadap cuaca, sehingga diperlukan 
penanganan khusus dalam proses pengepakan dan distribusinya [2].

Daya tahan ikan segar yang tidak lama, menjadi kendala dalam usaha perluasan pemasaran hasil perikanan. Bahkan sering menimbulkan kerugian besar pada saat produksi ikan melimpah [3]. Oleh karena itu, sejak lama masyarakat berusaha melakukan berbagai macam proses pengolahan pasca panen ikan guna meminimalkan kendala tersebut [4]. Pada dasarnya proses pengolahan pasca panen ikan bertujuan untuk mengurangi kadar air dalam daging ikan. Penurunan kadar air ini bisa menghambat perkembangbiakan mikroorganisme dalam daging ikan sehingga produk olahan ikan akan memiliki daya tahan lebih lama dibandingkan daging ikan segarnya [5]. Terdapat bermacammacam cara pengolahan pasca panen ikan mulai dari cara tradisional sampai modern. Salah satu diantara produk olahan ikan adalah abon ikan.

Pembuatan abon merupakan salah satu alternatif pengolahan ikan, untuk mengantisipasi kelimpahan produksi ataupun untuk penganekaragaman produk perikanan [6]. Abon ikan adalah jenis makanan awetan yang terbuat dari ikan laut yang diberi bumbu, diolah dengan cara perebusan dan penggorengan. Produk yang dihasilkan mempunyai bentuk lembut, rasa enak, bau khas, dan mempunyai daya awet yang relatif lama.

Jenis ikan yang dibuat sebagai bahan baku abon belum selektif, bahkan hampir semua jenis ikan dapat dijadikan abon. Namun demikian, akan lebih baik apabila dipilih jenis ikan yang mempunyai serat yang kasar dan tidak mengandung banyak duri [7].

Kualitas dapat diukur berdasarkan warna, aroma, rasa dan tekstur, melalui uji organoleptik [8]. Sifat organoleptik sangat penting bagi setiap produk karena berkaitan dengan penerimaan konsumen. Penilaian dengan organoleptik yang juga disebut dengan penilaian organoleptik atau penilaian sensoris, merupakan penilaian yang biasa diterapkan pada komoditi hasil pertanian [9], untuk mengukur tingkat kesukaan konsumen terhadap produk olahan. Penilaian organleptik mencakup aroma, rasa, warna dan tekstur dari produk.

Aroma disebut juga pencicipan jarak jauh karena manusia dapat mengenal enaknya makanan yang belum terlihat hanya dengan mencium aromanya dari jarak jauh. Manusia dapat mencium bau yang keluar dari makanan karena adanya sel-sel epitel alfaktori di bagian dinding atas rongga hidung yang peka terhadap komponen bau.

Rasa ialah sesuatu yang diterima oleh lidah. Dalam pengindraan cecapan dibagi empat cecapan utama yaitu manis, pahit, asam dan asin serta ada tambahan respon bila dilakukan modifikasi. Rasa dipengaruhi oleh beberapa komponen yaitu senyawa kimia, suhu, konsentrasi dan interaksi dengan komponen rasa yang lain.

Warna merupakan salah satu parameter selain cita rasa, tekstur dan nilai nutrisi yang menentukan persepsi konsumen terhadap suatu bahan pangan. Preferensi konsumen sering kali ditentukan berdasarkan penampakan luar suatu produk pangan. Warna pangan yang cerah memberikan daya tarik yang lebih terhadap konsumen. Warna pada produk pangan memiliki beberapa fungsi antara lain: sebagai indikator kematangan, terutama untuk produk pangan segar seperti buah-buahan, sebagai indikator kesegaran misalnya pada produk sayuran dan daging dan sebagai indikator kesempurnaan proses pengolahan pangan misalnya pada proses penggorengan.

Pengamatan tekstur pada abon ikan sangat penting dilakukan. Hal ini disebabkan karena tekstur merupakan salah satu hal yang membedakan abon ikan dengan produk perikanan lainya yaitu berupa serat-serat yang lembut. Tekstur daging sangat berpengaruh terhadap produk akhir yang dihasilkan dan menentukan tingkat kesukaan kosumen terhadap produk tersebut [10]. Penilaian kualitas abon ikan yang dilakukan secara organoleptik ini bersifat linguistik, sehingga variabel dan penentuan parameter yang bersifat tidak pasti, menjadi masalah yang harus dihadapi. Karena ketidakpastian variabel dan parameter yang digunakan, maka salah satu metode yang dapat diterapkan adalah dengan menggunakan logika fuzzy.

Logika fuzzy merupakan logika yang berhadapan langsung dengan konsep kebenaran sebagian. Hal ini berbeda dari logika klasik, yang menyatakan bahwa segala hal dapat dinyatakan dengan nilai keanggotaan 0 atau 1 , benar atau salah, panas atau dingin, A atau Tidak-A. Logika fuzzy memungkinkan hal tersebut dinyatakan dalam nilai keanggotaan antara 0 dan 1 , benar dan salah, panas dan dingin, serta A dan Tidak-A. Logika fuzzy menyediakan cara sederhana untuk menggambarkan kesimpulan pasti dari informasi yang ambigu, samar-samar, atau tidak tepat.

Logika fuzzy merupakan salah satu komponen pembentuk soft computing [11]. Logika fuzzy pertama kali diperkenalkan pada tahun 1965 oleh Prof. Lotfi A. Zadeh, seorang peneliti di Universitas California di Barkley dalam bidang ilmu komputer. Professor Zadeh beranggapan bahwa logika benar salah tidak dapat mewakili setiap pemikiran manusia. Dasar logika fuzzy adalah teori himpunan fuzzy. Pada teori himpunan fuzzy, peranan derajat 
keanggotaan sebagai penentu keberadaan elemen dalam suatu himpunan sangatlah penting. Nilai keanggotaan atau derajat keanggotaan atau membership function menjadi ciri utama dari penalaran dengan logika fuzzy tersebut.

Konfigurasi dasar dari sistem logika fuzzy yang digunakan seperti terlihat pada Gambar 1. Konfigurasi sistem logika fuzzy terdapat 4 komponen utama, yaitu unit fuzzifikasi, basis pengetahuan yang terdiri dari basis data dan basis aturan, logika pengambilan keputusan, dan unit defuzzifikasi. Proses fuzzifikasi dipergunakan untuk mengubah data masukkan tegas ke dalam bentuk derajat keanggotaan. Basis pengetahuan dipergunakan untuk menghubungkan himpunan masukan dengan himpunan keluaran. Logika pengambilan keputusan dipergunakan untuk mengkombinasi aturan-aturan yang terdapat pada basis aturan suatu pemetaan dari masukan suatu himpunan fuzzy ke luaran suatu himpunan fuzzy. Defuzzifikasi adalah langkah terakhir dalam sistem logika fuzzy dengan tujuannya untuk mengkonversi setiap hasil dari inference engine yang diekspresikan dalam bentuk himpunan fuzzy ke suatu bilangan real.

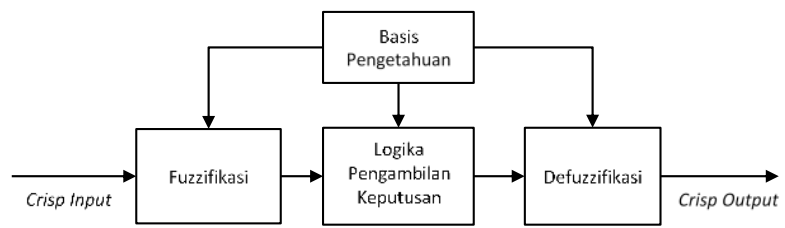

Gambar 1. Konfigurasi dasar sistem logika fuzzy

Penelitian ini bertujuan untuk: Mengetahui kualitas produk abon ikan berdasarkan tingkat kepuasan konsumen terhadap warna, aroma, rasa dan tekstur produk abon ikan, dengan pendekatan metode logika fuzzy.

\section{BAHAN DAN METODE}

\subsection{Persiapan Sarana Pengujian}

Pada penelitian ini, obyek penelitian adalah produk abon ikan yang diproduksi oleh Usaha Kecil dan Menengah (UKM) di kota Ambon. Prasarana, sarana dan peralatan yang dibutuhkan untuk pengujian organoleptik adalah:

Prasarana utama:

- tempat dengan lingkungan yang tenang

- suasana yang tenang, bersih, rapih, dan teratur

Sarana utama:

- ruang uji dengan beberapa kotak uji

- dapur penyiapan contoh

- peralatan penyajian contoh
- ruang penyiapan formulir/ format uji

- ruang pengarahan/ instruksi kepada tim panelis

- ruang tunggu panelis

Peralatan:

- alat penyiapan sampel

- alat penyajian sampel

- alat komunikasi (sistem lampu, format isian, format instruksi, alat tulis).

\subsection{Pemilihan Panelis}

Responden atau panelis adalah konsumen abon ikan, yang dipilih menggunakan Non Probability Sampling. Hal ini dilakukan karena alasan keterbatasan waktu dan dana penelitian. Dengan demikian, panelis digolongkan sebagai panel konsumen (consumer panel).

Indera yang digunakan dalam pengujian Organoleptik [12] adalah:

- Penglihatan: berhubungan dengan warna kilap, viskositas, ukuran dan bentuk, volume kerapatan dan berat jenis, panjang lebar dan diameter serta bentuk bahan.

- Indra peraba: berkaitan dengan struktur, tekstur dan konsistensi. Struktur merupakan sifat dari komponen penyusun, tekstur merupakan sensasi tekanan yang dapat diamati dengan mulut atau perabaan dengan jari, dan konsistensi merupakan tebal, tipis dan halus.

- Indra pembau: digunakan sebagai suatu indikator terjadinya kerusakan pada produk, misalnya ada bau busuk yang menandakan produk tersebut telah mengalami kerusakan.

- Indra pengecap: dalam hal kepekaan rasa, maka rasa manis dapat dengan mudah dirasakan pada ujung lidah, rasa asin pada ujung dan pinggir lidah, rasa asam pada pinggir lidah dan rasa pahit pada bagian belakang lidah.

\subsection{Metode Pengujian}

Panel diundang untuk melakukan pengujian di tempat yang telah ditentukan. Karena keterbatasan tempat, proses pengujian dilakukan secara bergilir. Masing-masing panelis akan diberikan sampel abon ikan yang ada, sehingga panelis bisa melihat, meraba, membaui dan mengecap rasanya. Masingmasing panelis kemudian akan memberikan penilaian berdasarkan kesukaannya, dengan rentang nilai 1 - 5 (sangat tidak suka - sangat suka). Skala hedonik yang digunakan serta kategorinya ditunjukkan pada Tabel 2.1. 
Tabel 1. Skala Hedonik Pengukuran Kualitas

\begin{tabular}{lll}
\hline Skala & Keterangan & Kategori \\
\hline 1 & Sangat tidak suka & Tidak suka \\
2 & Tidak suka & Netral \\
3 & Netral & \\
4 & Suka & Suka \\
5 & Sangat Suka & \\
\hline
\end{tabular}

\subsection{Validitas dan Reliabilitasi Instrumen}

Validitas mempunyai arti sejauh mana ketetapan dan kecermatan suatu alat ukur dalam melakukan fungsi ukurnya [13]. Suatu skala atau instrumen dapat dikatakan mempunyai validitas yang tinggi apabila instrumen tersebut menjalankan fungsi ukurnya.

Reliabilitas merupakan indeks yang menunjukkan sejauh mana hasil pengukuran alat tersebut dapat dipercaya [13].

\subsection{Metode Pengolahan Data}

Pengolahan data dengan logika fuzzy mengikuti algoritma berikut [14]:

1. Fuzzification

2. Fuzzy rule evaluation

3. Aggregation

4. Defuzzification

\section{HASIL DAN PEMBAHASAN} 3.1. Uji Organoleptik

Penelitian dilaksanakan di Fakultas Teknik Universitas Pattimura, untuk mengetahui uji organoleptik (warna, tekstur, aroma, dan rasa) abon ikan. Uji organoleptik merupakan cara pengujian dengan menggunakan indera manusia sebagai alat utama untuk pengukuran daya penerimaan terhadap produk. Jenis uji organoleptik yang digunakan adalah uji kesukaan atau hedonik yang menyatakan suka atau tidaknya suatu produk. Penelitian ini menggunakan panelis konsumen yang berjumlah 50 orang, yang merupakan mahasiswa Fakultas Teknik Universitas Pattimura.

Panelis dimintakan tanggapan pribadinya tentang kesukaan atau sebaliknya (ketidaksukaan). Disamping panelis mengemukakan tanggapan senang, suka atau kebalikannya, mereka juga mengemukakan tingkat kesukaannya. Tingkat kesukaan ini disebut skala hedonik, dengan rentang nilai 1 - 5 (sangat tidak menyukai - sangat menyukai), serta terdapat tanggapannya yang disebut sebagai netral (nilai 3), yaitu bukan suka tetapi juga bukan tidak suka (neither like nor dislike). Hasil selengkapnya pengumpulan data ditampilkan pada Lampiran 1.

\subsection{Uji Validitas dan Reliabilitas}

Hasil uji validitas terlihat pada Tabel 2. Dapat disimpulkan bahwa seluruh variabel yang diuji valid untuk dilanjutkan ke pengukuran selanjutnya. Hal ini ditunjang dengan nilai P-value yang seluruhnya 0,000 .

Tabel 2. Hasil uji validitas

\begin{tabular}{ccccc}
\hline & Warna & Tekstur & Aroma & Rasa \\
\hline Tekstur & 0.234 & & & \\
& 0.102 & & & \\
Aroma & 0.228 & 0.325 & & \\
& 0.111 & 0.021 & & \\
Rasa & 0.275 & 0.583 & 0.371 & \\
& 0.054 & 0.000 & 0.008 & \\
Total & 0.534 & 0.739 & 0.730 & 0.812 \\
& 0.000 & 0.000 & 0.000 & 0.000 \\
\hline
\end{tabular}

Hasil uji Reliabilitas menunjukkan nilai Cronbach-Alpha sebesar 0,6645. Hasil ini menunjukkan bahwa hasil pengukuran dapat dipercaya untuk dilakukan pengolahan data selanjutnya.

\subsection{Analisis Hasil Uji Organoleptik}

Secara keseluruhan, data hasil uji daya terima warna, tekstur, aroma dan rasa dari abon ikan dapat disajikan sebagaimana pada Tabel 3.

Tabel 3. Rekapitulasi Hasil Uji Daya Terima Abon Ikan

\begin{tabular}{ccccccccc}
\hline Skala & \multicolumn{2}{c}{ Warna } & \multicolumn{2}{c}{ Tekstur } & \multicolumn{2}{c}{ Aroma } & \multicolumn{2}{c}{ Rasa } \\
\cline { 2 - 8 } Hedonik & $\boldsymbol{n}$ & $\boldsymbol{\%}$ & $\boldsymbol{n}$ & $\mathbf{\%}$ & $\boldsymbol{n}$ & $\mathbf{\%}$ & $\boldsymbol{n}$ & $\mathbf{\%}$ \\
\hline $\mathbf{1}$ & 0 & $0 \%$ & 0 & $0 \%$ & 0 & $0 \%$ & 1 & $2 \%$ \\
$\mathbf{2}$ & 0 & $0 \%$ & 2 & $4 \%$ & 7 & $14 \%$ & 2 & $4 \%$ \\
$\mathbf{3}$ & 10 & $20 \%$ & 3 & $6 \%$ & 1 & $2 \%$ & 2 & $4 \%$ \\
$\mathbf{4}$ & 34 & $68 \%$ & 33 & $66 \%$ & 28 & $56 \%$ & 12 & $24 \%$ \\
$\mathbf{5}$ & 6 & $12 \%$ & 12 & $24 \%$ & 14 & $28 \%$ & 33 & $66 \%$ \\
\hline
\end{tabular}

\subsection{Analisis Fuzzy}

Data yang diperoleh dalam penelitian, pengolahannya menggunakan metode fuzzy mamdani. Terdapat lima tahapan pada metode fuzzy mamdani dalam memperoleh output yaitu penentuan fuzzy set, fuzzyfikasi, pembentukan aturan fuzzy, inferensi dan defuzzyfikasi. 


\section{a. Membuat Variabel Fuzzy}

Pada permasalahan ini, varibel input yang digunakan adalah warna, tekstur, aroma dan rasa. Variabel outputnya berupa kualitas abon ikan.

Tabel 4. Himpunan Fuzzy Input dan Output

\begin{tabular}{|c|c|c|c|c|}
\hline Fungsi & Variabel & Himpunan & Semesta & Domair \\
\hline \multirow[t]{20}{*}{ Input } & \multirow[t]{5}{*}{ Warna } & Sangat tidak suka & [1 5] & $\left.\begin{array}{lll} & 1 & 2\end{array}\right]$ \\
\hline & & Tidak suka & {$\left[\begin{array}{ll}1 & 5\end{array}\right]$} & {$\left[\begin{array}{lll}1 & 2 & 3\end{array}\right]$} \\
\hline & & Netral & [1 5] & {$\left[\begin{array}{lll}2 & 3 & 4\end{array}\right]$} \\
\hline & & Suka & {$\left[\begin{array}{ll}1 & 5\end{array}\right]$} & {$\left[\begin{array}{lll}3 & 4 & 5\end{array}\right]$} \\
\hline & & Sangat suka & [1 5] & {$\left[\begin{array}{lll}4 & 5 & 5\end{array}\right]$} \\
\hline & \multirow[t]{5}{*}{ Tekstur } & Sangat tidak suka & [1 5] & {$\left[\begin{array}{lll}1 & 1 & 2\end{array}\right]$} \\
\hline & & Tidak suka & {$\left[\begin{array}{ll}1 & 5\end{array}\right]$} & {$\left[\begin{array}{lll}1 & 2 & 3\end{array}\right]$} \\
\hline & & Netral & {$\left[\begin{array}{ll}1 & 5\end{array}\right]$} & {$\left[\begin{array}{lll}2 & 3 & 4\end{array}\right]$} \\
\hline & & Suka & [1 5] & {$\left[\begin{array}{lll}3 & 4 & 5\end{array}\right]$} \\
\hline & & Sangat suka & {$\left[\begin{array}{ll}1 & 5\end{array}\right]$} & {$\left[\begin{array}{lll}4 & 5 & 5\end{array}\right]$} \\
\hline & \multirow[t]{5}{*}{ Aroma } & Sangat tidak suka & {$\left[\begin{array}{ll}1 & 5\end{array}\right]$} & {$\left[\begin{array}{lll}1 & 1 & 2\end{array}\right]$} \\
\hline & & Tidak suka & {$\left[\begin{array}{ll}1 & 5\end{array}\right]$} & {$\left[\begin{array}{lll}1 & 2 & 3\end{array}\right]$} \\
\hline & & Netral & {$\left[\begin{array}{ll}1 & 5\end{array}\right]$} & {$\left[\begin{array}{lll}2 & 3 & 4\end{array}\right]$} \\
\hline & & Suka & {$\left[\begin{array}{ll}1 & 5\end{array}\right]$} & {$\left[\begin{array}{lll}3 & 4 & 5\end{array}\right]$} \\
\hline & & Sangat suka & [1 5] & {$\left[\begin{array}{lll}4 & 5 & 5\end{array}\right]$} \\
\hline & \multirow[t]{5}{*}{ Rasa } & Sangat tidak suka & {$\left[\begin{array}{ll}1 & 5\end{array}\right]$} & {$\left[\begin{array}{lll}1 & 1 & 2\end{array}\right]$} \\
\hline & & Tidak suka & {$\left[\begin{array}{ll}1 & 5\end{array}\right]$} & {$\left[\begin{array}{lll}1 & 2 & 3\end{array}\right]$} \\
\hline & & Netral & {$\left[\begin{array}{ll}1 & 5\end{array}\right]$} & {$\left[\begin{array}{lll}2 & 3 & 4\end{array}\right]$} \\
\hline & & Suka & {$\left[\begin{array}{ll}1 & 5\end{array}\right]$} & {$\left[\begin{array}{lll}3 & 4 & 5\end{array}\right]$} \\
\hline & & Sangat suka & {$\left[\begin{array}{ll}1 & 5\end{array}\right]$} & {$\left[\begin{array}{lll}4 & 5 & 5\end{array}\right]$} \\
\hline \multirow[t]{4}{*}{ Output } & \multirow[t]{4}{*}{ Kualitas } & Sangat Buruk & {$\left[\begin{array}{ll}1 & 5\end{array}\right]$} & {$\left[\begin{array}{lll}1 & 1 & 2\end{array}\right]$} \\
\hline & & Buruk & [1 5] & {$\left[\begin{array}{lll}1 & 2 & 3\end{array}\right]$} \\
\hline & & Netral & {$\left[\begin{array}{ll}1 & 5\end{array}\right]$} & {$\left[\begin{array}{lll}2 & 3 & 4\end{array}\right]$} \\
\hline & & $\begin{array}{l}\text { Baik } \\
\text { Sangat baik }\end{array}$ & 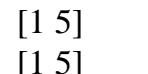 & $\begin{array}{l}{\left[\begin{array}{lll}3 & 4 & 5\end{array}\right]} \\
{\left[\begin{array}{lll}4 & 5 & 5\end{array}\right]}\end{array}$ \\
\hline
\end{tabular}

\section{b. Melakukan Fuzzyfikasi}

Variabel Warna, Tekstur, aroma dan rasa memiliki 5 (lima) himpunan yaitu sangat tidak suka, tidak suka, netral, suka dan sangat suka. Fungsi keanggotaan variabel ditunjukkan pada Gambar 2.

\section{c. Pembentukan Aturan Fuzzy}

Tahap selanjutnya adalah menyusun aturanaturan (rules) logika fuzzy. Berdasarkan data yang ada, diperoleh aturan-aturan sebagai berikut dengan "If warna, and tekstur, and aroma, and rasa then kualitas". Contoh aturan-aturan logika fuzzy dapat dilihat pada Tabel 5. Sebagai contoh: IF Warna "Sangat tidak setuju", AND Tekstur "Sangat tidak setuju" AND Aroma "Sangat tidak setuju" AND Rasa "Sangat tidak setuju, THEN Kualitas "Sangat buruk".

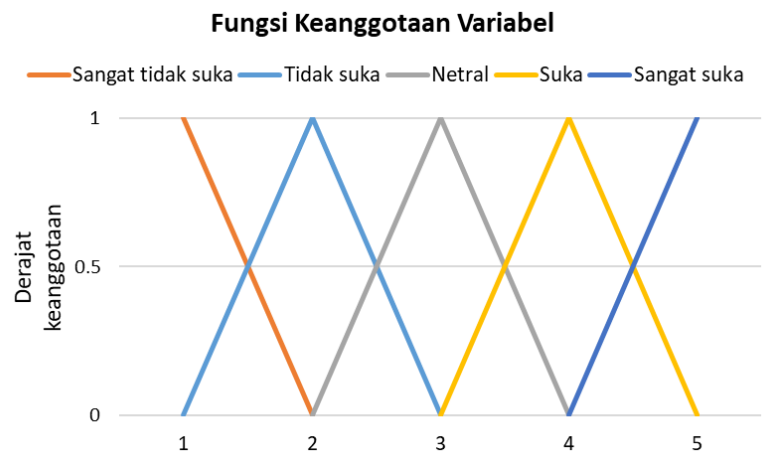

Gambar 2. Fungsi Keanggotaan Variabel

\section{d. Analisis Fuzzy Menggunakan Matlab}

Desain logika fuzzy dengan Matlab dapat dilihat pada Lampiran 1. Model terdiri dari 4 (empat) input, yaitu warna, tekstur, aroma dan rasa, serta memiliki 1 (satu) output, yaitu kualitas.

Data organoleptik terhadap kualitas abon ikan dengan metode fuzzy mamdani, dilakukan juga menggunakan Toolbox Fuzzy Matlab, yang berfungsi untuk menghitung nilai variabel kualitas abon ikan. Adapun nilai rata-ratanya kriteria warna adalah 3,92, nilai rata-rata kriteria tekstur sebesar 4,10 , rata-rata kriteria aroma sebesar 3,98 dan ratarata kriteria rasa sebesar 4,48. Hasil perhitungan kualitas dengan Matlab ditunjukkan pada Lampiran 2, yang menunjukan nilai kualitas abon ikan menggunakan logika fuzzy dengan bantuan software Matlab adalah 4,12

Tabel 5. Contoh Aturan Logika Fuzzy

\begin{tabular}{ccccc}
\hline IF & AND & AND & AND & THEN \\
Warna & Tekstur & Aroma & Rasa & Kualitas \\
\hline Sangat tidak setuju & Sangat tidak setuju & Sangat tidak setuju & Sangat tidak setuju & Sangat buruk \\
Sangat tidak setuju & Sangat tidak setuju & Sangat tidak setuju & Tidak setuju & Sangat buruk \\
Sangat tidak setuju & Sangat tidak setuju & Sangat tidak setuju & Netral & Sangat buruk \\
Sangat tidak setuju & Sangat tidak setuju & Sangat tidak setuju & Setuju & Sangat buruk \\
Sangat tidak setuju & Sangat tidak setuju & Sangat tidak setuju & Sangat setuju & Buruk \\
\hline
\end{tabular}




\begin{tabular}{ccccc}
\hline IF & AND & AND & AND & THEN \\
Warna & Tekstur & Aroma & Rasa & Kualitas \\
\hline Sangat tidak setuju & Sangat tidak setuju & Tidak setuju & Sangat tidak setuju & Sangat buruk \\
Sangat tidak setuju & Sangat tidak setuju & Tidak setuju & Tidak setuju & Sangat buruk \\
Sangat tidak setuju & Sangat tidak setuju & Tidak setuju & Netral & Sangat buruk \\
Sangat tidak setuju & Sangat tidak setuju & Tidak setuju & Setuju & Buruk \\
Sangat tidak setuju & Sangat tidak setuju & Tidak setuju & Sangat setuju & Buruk \\
\hline
\end{tabular}

\section{e. Defuzzyfikasi}

Output Matlab menunjukkan beberapa hal sebagai berikut:

1. Input, meliputi:

a) Warna, dengan nilai riil sebesar 3,92, merupakan keanggotaan dari domain himpunan bilangan fuzzy Netral [l $\left.\begin{array}{lll}2 & 3 & 4\end{array}\right]$ dan Suka [ $\left.\begin{array}{lll}3 & 4 & 5\end{array}\right]$.

b) Tekstur, dengan nilai riil sebesar 4,10, merupakan keanggotaan dari domain himpunan bilangan fuzzy Suka [3 4 5 5 ] dan Sangat suka [ 45 5 5].

c) Aroma, dengan nilai riil sebesar 3,98, merupakan keanggotaan dari domain himpunan fuzzy Netral [2 33 4] dan Suka [3 4 5].

d) Rasa, dengan nilai riil sebesar 4,48, merupakan keanggotaan dari domain himpunan fuzzy Suka [3 4 5] dan Sangat suka [ [ $\left.\begin{array}{lll}4 & 5 & 5\end{array}\right]$.

2. Output, meliputi:

a) Kualitas, dengan nilai riil sebesar 4,12, merupakan keanggotaan dari domain himpunan bilangan fuzzy Baik [3 4 5] dan Sangat baik [ 45 5 5 .

\section{KESIMPULAN}

Berdasarkan pembahasan pada Bab sebelumnya, dapat dapat disimpulkan beberapa hal sebagai berikut:

1. Konsumen menilai bahwa variabel warna dan aroma berada di antara domain Netral dan Suka (nilai riil 3,92 dan 3,98), sementara variabel tekstur dan rasa berada di antara domain Suka dan Sangat suka (nilai riil 4,1 dan 4,48). Sehingga, secara umum konsumen lebih menyukai tekstur dan rasa abon ikan, dibandingkan dengan warna dan aromanya.

2. Kualitas abon ikan berada di antara domain Baik dan Sangat baik, dengan nilai riil 4,12. Sehingga, konsumen secara umum menganggap bahwa kualitas abon ikan sudah baik.

\section{UCAPAN TERIMA KASIH}

Penelitian ini terlaksana atas bantuan Dana
Penelitian yang berasal dari PNBP Fakultas Teknik tahun 2019. Untuk itu, penulis menyampaikan terima kasih kepada Pimpinan Fakultas Teknik Universitas Pattimura.

\section{DAFTAR PUSTAKA}

[1] E. Suwondo and A. D. Guritno, "Mapping Sistem Logistik Produk Ikan Tangkap Segar di Daerah Pesisir Pantai Jawa," presented at the Seminar Agroindustri dan Lokakarya Nasional FKPT-TPI, Sep. 2015.

[2] S. B. Atmaja and D. Nugroho, "Upaya-upaya Pengelolaan Sumber Daya Ikan yang Berkelanjutan di Indonesia," J. Kebijak. Perikan. Indones., vol. 3, no. 2, pp. 101-113, Feb. 2017, doi: 10.15578/jkpi.3.2.2011.101113.

[3] M. Dzulmawan, L. Geo, and A. Gafaruddin, "Analisis Nilai Tambah Pengolahan Abon Ikan Tuna di Kelurahan Mata Kecamatan Kendari Kota Kendari (Studi Kasus Industri Rumah Tangga Dzakiyah Permata)," J. Ilm. Agribisnis, vol. 4, no. 2, p. 281397, 2019, doi: 10.33772/jia.v4i2.6511.

[4] Moh. N. Syafar and A. Lamusa, "Analisis Pendapatan Usaha Abon Ikan Tenggiri Pada Industri Rumah Tangga 'Althaf Food' di Kota Palu," E-J. Agrotekbis, vol. 3, no. 2, pp. 255260, 2015.

[5] E. Afrianto and E. Liviawaty, Pengawetan dan Pengolahan Ikan. Yogyakarta: Kanisius, 1989.

[6] E. Aryani, "Kajian pemberian asam askorbat (vitamin C) dengan konsentrasi yang berbeda terhadap ketengikan abon ikan lele (clarias batrachus)," Fish Sci., vol. 4, no. 7, Jun. 2016, doi: $10.20527 /$ fs.v4i7.1126.

[7] T. Leksono and Syahrul, "Studi Mutu dan Penerimaan Konsumen terhadap Abon," $J$. Nat. Indones., vol. 3, no. 2, pp. 178-184, 2001.

[8] D. Fishken, "Sensory Quality and the Consumer: Viewpoints and Directions," $J$. Sens. Stud., vol. 5, no. 3, pp. 203-209, 1990, doi: 10.1111/j.1745-459X.1990.tb00490.x.

[9] E. Hasrati and R. Rusnawati, "Kajian Penggunaan Daging Ikan Mas (Cyprinus Carpio Linn) terhadap Tekstur dan Cita Rasa 
Bakso Daging Sapi," Agromedia, vol. 29, no. 1, Mar. 2011, Accessed: Apr. 06, 2019. [Online].

[10] S. T. Miratis, T. D. Sulistiyati, and H. E. Suprayitno, "Pengaruh Suhu Pengukusan terhadap Kandungan Gizi dan Organoleptik Abon Ikan Gabus (Ophiocephalus striatus)," $J$. Mhs. Teknol. Has. Perikan., vol. 1, no. 1, pp. 33-45-45, May 2013.

[11] M. Jedlickova and P. Kutnar, "Construction of a Fuzzy Model for the Success Prediction of Hi-Tech Companies With a Short History," in 17th International Scientific Conference at Brno University of Technology, Faculty of Business and Management, Brno, Czech Republic, Apr. 2019, vol. 0, Accessed: Apr. 14, 2019. [Online]. Available: https://conference.fbm.vutbr.cz/ic/index.php/i c/article/view/36.

[12] Waysima and D. Adawiyah R., Evaluasi Sensori, 5th ed. Bogor: Fakultas Teknologi Pertanian Institut Pertanian Bogor, 2001.

[13] R. Heale and A. Twycross, "Validity and reliability in quantitative studies," Evid. Based Nurs., vol. 18, no. 3, pp. 66-67, Jul. 2015, doi: 10.1136/eb-2015-102129.

[14] P. Vonglao, "Application of fuzzy logic to improve the Likert scale to measure latent variables," Kasetsart J. Soc. Sci., vol. 38, no. 3, pp. 337-344, Sep. 2017, doi: 10.1016/j.kjss.2017.01.002. 
Lampiran 1. Desain logika fuzzy dengan Matlab
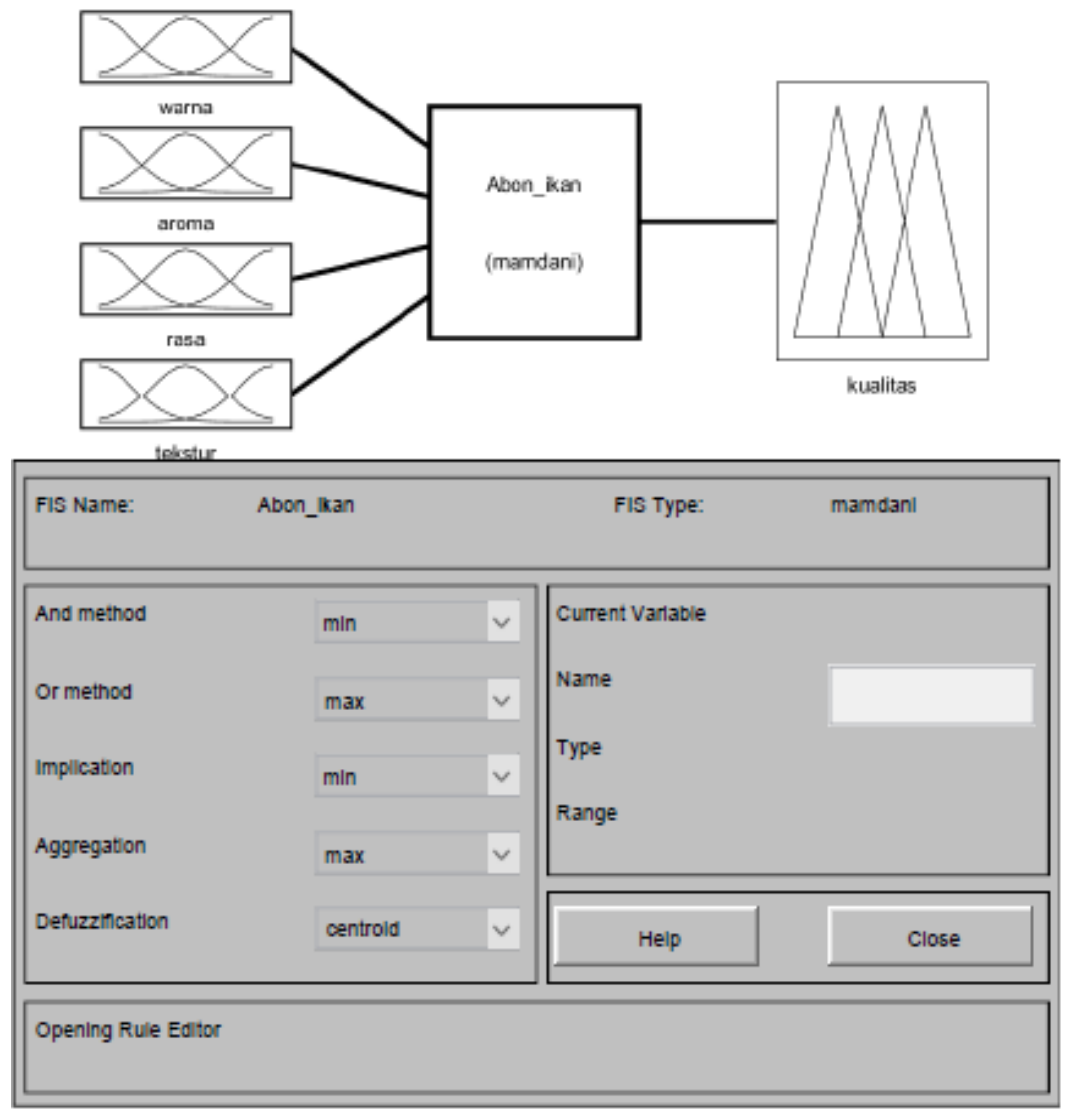

Lampiran 2 Hasil perhitungan kualitas abon ikan dengan Matlab 


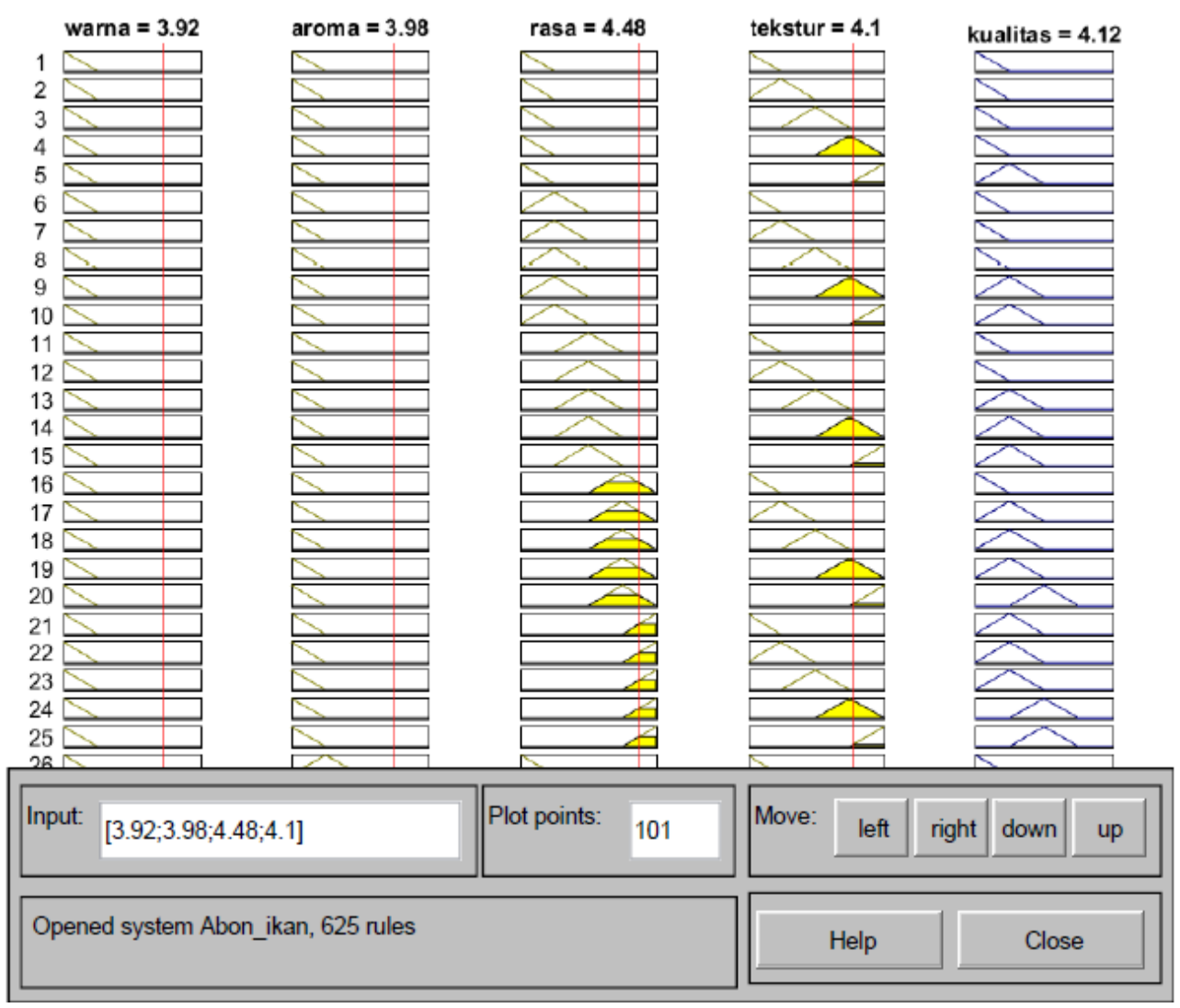

